\title{
Effect of negative air ions on the potential for bacterial contamination of plastic medical equipment
}

\author{
Simon J Shepherd ${ }^{1}$, Clive B Beggs ${ }^{* 1}$, Caroline F Smith¹, Kevin G Kerr ${ }^{1,2}$, Catherine J Noakes ${ }^{3}$ and P Andrew Sleigh ${ }^{3}$
}

\begin{abstract}
Background: In recent years there has been renewed interest in the use of air ionizers to control the spread of infection in hospitals and a number of researchers have investigated the biocidal action of ions in both air and nitrogen. By comparison, the physical action of air ions on bacterial dissemination and deposition has largely been ignored. However, there is clinical evidence that air ions might play an important role in preventing the transmission of Acinetobacter infection. Although the reasons for this are unclear, it is hypothesized that a physical effect may be responsible: the production of air ions may negatively charge items of plastic medical equipment so that they repel, rather than attract, airborne bacteria. By negatively charging both particles in the air and items of plastic equipment, the ionizers minimize electrostatic deposition on these items. In so doing they may help to interrupt the transmission of Acinetobacter infection in certain healthcare settings such as intensive care units.
\end{abstract}

Methods: A study was undertaken in a mechanically ventilated room under ambient conditions to accurately measure changes in surface potential exhibited by items of plastic medical equipment in the presence of negative air ions. Plastic items were suspended on nylon threads, either in free space or in contact with a table surface, and exposed to negative ions produced by an air ionizer. The charge build-up on the specimens was measured using an electric field mill while the ion concentration in the room air was recorded using a portable ion counter.

Results: The results of the study demonstrated that common items of equipment such as ventilator tubes rapidly developed a large negative charge (i.e. generally $>-100 \mathrm{~V}$ ) in the presence of a negative air ionizer. While most items of equipment tested behaved in a similar manner to this, one item, a box from a urological collection and monitoring system (the only item made from styrene acrylonitrile), did however develop a positive charge in the presence of the ionizer.

Conclusion: The findings of the study suggest that the action of negative air ionizers significantly alters the electrostatic landscape of the clinical environment, and that this has the potential to cause any Acinetobacter-bearing particles in the air to be strongly repelled from some plastic surfaces and attracted to others. In so doing, this may prevent critical items of equipment from becoming contaminated with the bacterium.

\section{Background}

In recent years there has been renewed interest in the use of air ionizers to control the spread of infection in hospitals [1] and a number of researchers have investigated the biocidal action of ions in both air [2-9] and nitrogen $[2,10]$. While the physical action of air ions on particles has received some attention [11-14] the role of ionizers in

*Correspondence: c.b.beggs@bradford.ac.uk

1 Bradford Infection Group, School of Engineering, Design and Technology, University of Bradford, Bradford, BD7 1DP, UK

Full list of author information is available at the end of the article bacterial dissemination and deposition has largely been ignored. However, there is evidence from a clinical setting that air ions might play an important role in preventing the transmission of some infections. In a trial conducted on an intensive care unit (ICU), Kerr et al. [1] found that the presence of negative air ionizers was associated with a significant decrease Acinetobacter infection or patient colonization, despite the fact that numbers of environmental isolates of Acinetobacter spp increased. This suggests that the observed reduction in Acinetobacter 
infection or patient colonization was probably due to physical effects rather than any bactericidal phenomena. Although the reasons for the results observed by Kerr et al. [1] are unclear, it is hypothesized that the air ions may have negatively charged items of plastic medical equipment in the ward, such as patient ventilator tubes, so that they repelled, rather than attracted, airborne bacteria. Widespread aerial dissemination of bacteria is thought to occur within the clinical environment $[15,16]$ due to activities such as bed making, and this has been implicated in a number of outbreaks of Acinetobacter infection [17-19]. In the course of normal operation, many items of plastic equipment naturally acquire an electric charge [20], and this can promote electrostatic precipitation of bacteria, carrying an opposed charge, from the air. By negatively charging both particles in the air and items of plastic equipment, the ionizers potentially minimize electrostatic deposition on these surfaces. In order to test this hypothesis we designed the experimental study to investigate the behaviour of items of plastic medical equipment in the presence of negative air ions and to assess the likely impact on the precipitation of airborne particles.

\section{Methods}

The study was undertaken in a mechanically ventilated room (dimensions $3 \times 2 \times 2.5 \mathrm{~m}$ high) under ambient conditions. The aim of the study was to measure accurately changes in surface potential exhibited by items of plastic medical equipment in the presence of negative air ions. During experimentation plastic items were suspended on nylon threads, either in free space or in contact with a table surface (see Figure 1), and exposed to negative ions produced by a direct current unipoler air ionizer (WM 120, Air Ion Technologies Limited, New Milton, UK) with an electrode potential of $-5 \mathrm{kV}$. Items examined were: ventilator tubing (Breathing System 2000, Intersurgical Ltd, Wokingham, UK); a ventilator mask (SealFlex ${ }^{\text {tw }}$ single port, Caradyne Ltd, Dublin, Ireland); nebulizer tubing (MicroMist ${ }^{\mathrm{mw}}$, Hudson Respiratory Care Inc, North Carolina, USA); Unometer ${ }^{\text {tw }}$ measuring chamber and collection tubing (both Unomedical Ltd, Redditch, UK) and a disposable apron (BPI Healthcare, Heanor, UK). The charge build-up on the specimens was measured using an electric field mill (JCI 140, John Chubb Instrumentation, Cheltenham, UK), which was located perpendicular to the specimen surface at a distance of $100 \mathrm{~mm}$. During the various experiments the ion concentration in the room air was recorded using a portable ion counter (Air Ion Counter IC 1000, Ion Trading, Tokyo, Japan). The air temperature and humidity in the room space were also recorded.

Table 1 lists the items tested, together with their dimensional and material characteristics. Each item of equipment was tested for a total of $3600 \mathrm{~s}$ - an initial period of

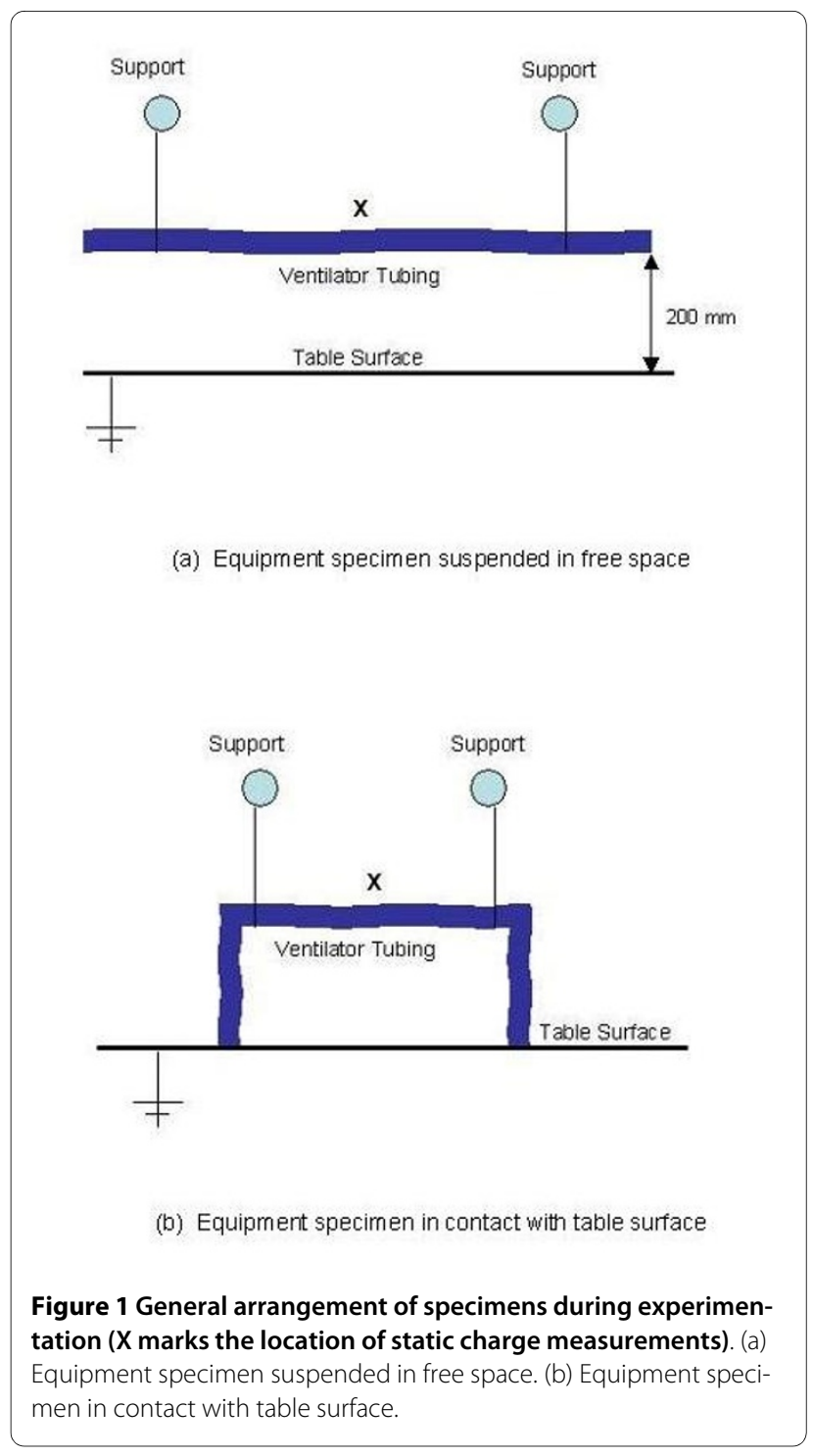

$600 \mathrm{~s}$ in which the ionizer was not in operation, a second period of $2200 \mathrm{~s}$ in which the ionizer was in operation, and a final period of $800 \mathrm{~s}$ in which the ionizer was again inoperative. The surface potential was recorded every 30 $\mathrm{s}$. This regime was selected because it allowed the transient charge build-up and decay to be characterized for each specimen item of equipment.

In order to characterize the electrical properties of the test apparatus described above, we arranged a LDPE ventilator tube as shown in Figure 1(b), so that its ends were in contact with the table top. We then charged the tube by rubbing it with a cloth and recorded the subsequent discharge over a 5 minute period. The results of this experiment are presented in Figure 2. From this it can be seen that the charge decay is exponential, with a $C R$ constant of approximately 140 seconds, which corresponds to a leakage resistance of about $10^{13} \Omega$ and a capacitance of 14 $\mathrm{pF}$. When the procedure was repeated for the ventilator 
Table 1: Characteristics of the items of equipment used in the study

\begin{tabular}{|c|c|c|c|c|c|}
\hline $\begin{array}{l}\text { Item of } \\
\text { Equipment }\end{array}$ & Description & Component Tested & Component Material & $\begin{array}{l}\text { Characteristic } \\
\text { Dimension }\end{array}$ & $\begin{array}{l}\text { Relative Electrical } \\
\text { Permittivity @ } 1 \text { Mhz }\end{array}$ \\
\hline Ventilator tubing & $\begin{array}{l}\text { Parallel twin plastic ventilator } \\
\text { tubes }(1.6 \mathrm{~m} \text { long })\end{array}$ & $\begin{array}{l}\text { Centre portion of } \\
\text { tube }\end{array}$ & $\begin{array}{l}\text { Low density } \\
\text { polyethylene (LDPE) }\end{array}$ & $\begin{array}{l}25 \mathrm{~mm} \text { external } \\
\text { diameter tube }\end{array}$ & $2.2-2.35$ \\
\hline Ventilator Mask & $\begin{array}{l}\text { Single port mask with } \\
\text { attachment for ventilator } \\
\text { tubing }\end{array}$ & Mask & $\begin{array}{l}\text { Cushion } \\
\text { Thermoplastic } \\
\text { elastomer } \\
\text { (TPE) }\end{array}$ & $\begin{array}{l}\text { Height: } 110 \mathrm{~mm} \\
\text { Width: } 85 \mathrm{~mm} \\
\text { Depth: } 42 \mathrm{~mm}\end{array}$ & Unknown \\
\hline Nebulizer tubing & $\begin{array}{l}\text { Nebulizer with reservoir } \\
\text { tubing }\end{array}$ & Reservoir tubing & $\begin{array}{l}\text { Polyvinylchloride } \\
\text { (PVC) }\end{array}$ & $\begin{array}{l}6 \text { mm external } \\
\text { diameter tube }\end{array}$ & 2.8 \\
\hline $\begin{array}{l}\text { Unometer }^{\mathrm{TM}} \text { box } \\
\text { and tubing }\end{array}$ & $\begin{array}{l}\text { Urological collection and } \\
\text { monitoring system with } \\
\text { collection bag }\end{array}$ & $\begin{array}{l}\text { Plastic measuring } \\
\text { box }\end{array}$ & $\begin{array}{l}\text { Styrene acrylonitrile } \\
\text { (SAN) }\end{array}$ & $\begin{array}{l}\text { Height: } 105 \mathrm{~mm} \\
\text { Width: } 180 \mathrm{~mm} \\
\text { Depth: } 45 \mathrm{~mm}\end{array}$ & $2.55-2.95$ \\
\hline $\begin{array}{l}\text { Unometer }^{\mathrm{TM}} \text { box } \\
\text { and tubing }\end{array}$ & $\begin{array}{l}\text { Urological collection and } \\
\text { monitoring system with } \\
\text { collection bag }\end{array}$ & Tubing & $\begin{array}{l}\text { Polyvinylchloride } \\
\text { (PVC) }\end{array}$ & $\begin{array}{l}9 \text { mm external } \\
\text { diameter tube }\end{array}$ & 2.8 \\
\hline Disposable Apron & Plastic disposable Apron & Apron & Polyethylene (PE) & $\begin{array}{l}265 \mathrm{~mm} \times 275 \\
\mathrm{~mm}\end{array}$ & 2.3 \\
\hline
\end{tabular}

tubing suspended in free space (i.e. without contact with the table), no significant discharge was recorded. In order to calculate the strength of the electric field around the ventilator tubing equation 1 was used.

$$
E=\frac{q}{4 \pi \varepsilon_{0} \varepsilon_{r} r^{2}}
$$

Where, $q$, is the charge on the surface of the plastic tube, $\varepsilon_{0}$ is the permittivity of free space which is approximately $8.854 \times 10^{-12} \mathrm{~F} / \mathrm{m}, \varepsilon_{\mathrm{r}}$ is the relative permittivity of the tubing material and $r$ is the radius of the tube.

\section{Results}

The ion count and air condition data recorded during the various experiments are presented in Table 2 . From these data it can be seen that under normal conditions (i.e. without the ionizer in operation), the negative air ion count in the test room was generally $<1000 \mathrm{ions} / \mathrm{cm}^{3}$. However, when the negative ion generator was in operation, the negative ion count rapidly increased to stabilize at values in the range $28800-85600$ ions $/ \mathrm{cm}^{3}$. During the experiments conditions in the test room were recorded and found to be stable with relatively little variation in air temperature or humidity.

The results of the experiments on the various items of equipment are presented in figures $3,4,5,6,7$ and 8 below. These show sequential plots of the potential recorded on the surface of the various specimen items. From these, it can be seen that, with the exception of the disposable apron (Figure 8) and the Unometer ${ }^{\mathrm{mm}}$ plastic measuring box (Figure 6), the other items of medical equipment all behaved in a similar fashion when the ionizer was in operation - they all rapidly developed a large negative charge (i.e. generally $>-100 \mathrm{~V}$ ) in the presence of the ionizer. However once the ionizer was switched off, all these specimens quickly lost their large negative charge and returned to a steady slightly negative $(<-50 \mathrm{~V})$ potential (figures 3, 4, 5 and 7). Whether or not the item of equipment was in contact with the earthed table appeared to matter little - in both cases the negative potential developed during ionization was approximately the same. In the case of the nebulizer and Unometer $^{\text {Tux }}$ urinary tubing, when these items of equipment were in contact with the table there appears to have been a gradual leaking of charge to earth.

The results obtained for the disposable apron and the Unometer $^{\mathrm{m}}$ measuring chamber were somewhat different from those for the other items of equipment. When sus- 


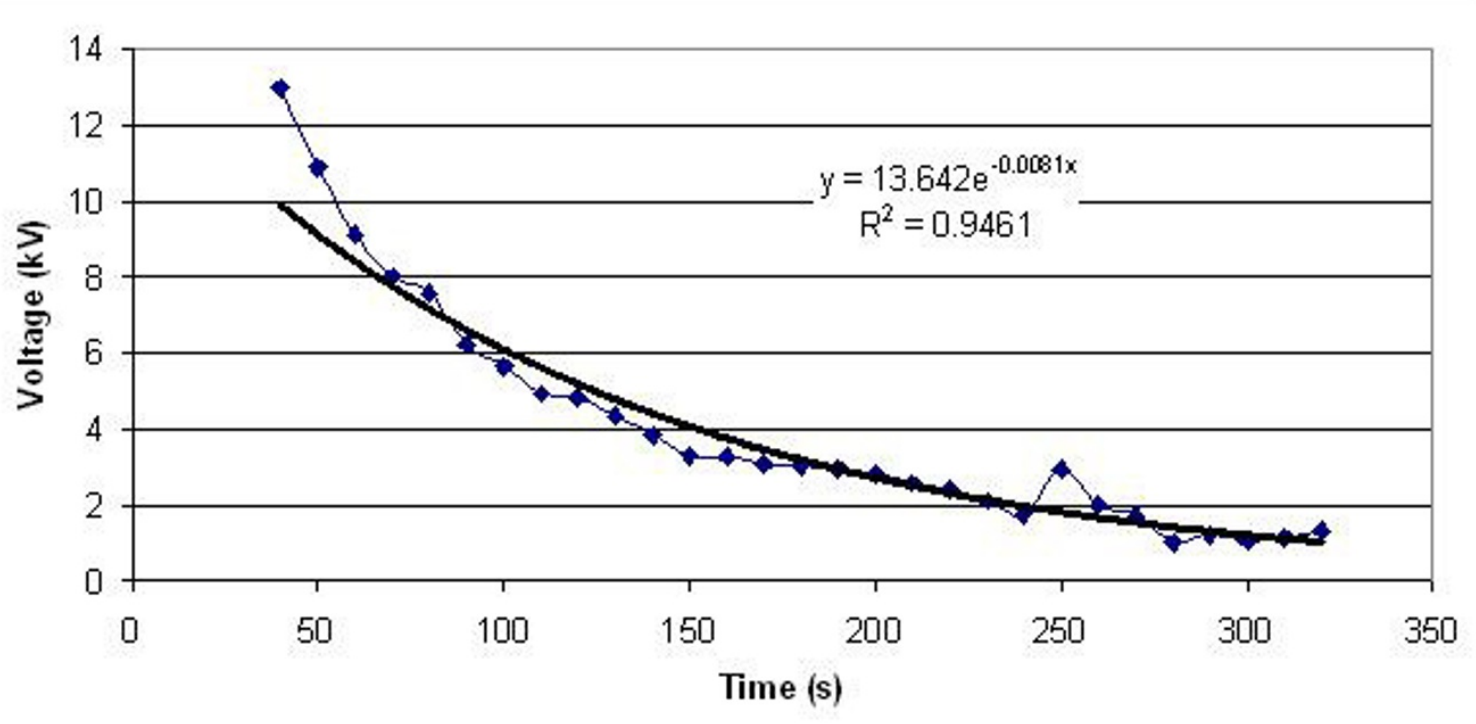

Figure 2 Charge decay in a ventilator tube suspended with its ends in contact with an earthed table

pended in free space the Unometer ${ }^{\mathrm{Tw}}$ chamber acquired a positive surface potential in the region $700-1000 \mathrm{~V}$, which remained after the ionizer was switched off. However when the box was in contact with the table, the action of the ionizer steadily reduced the very high initial positive potential to a level similar to that recorded when the Unometer ${ }^{\mathrm{m}}$ box was in free space. As with the free space experiment, when the ionizer was switched off the surface potential of the box remained steady at approximately $+1000 \mathrm{~V}$. These data suggest that the polymer used to construct the box has radically different triboelectric properties to the polymer used in the Unometer ${ }^{\mathrm{m}}$ urinary tubing. By comparison, the results for the polyethylene apron appear less consistent. When in free space, the action of the ionizer on the apron was similar to that on the Unometer ${ }^{\mathrm{ma}}$ box - that is, the action of the ionizer caused the surface potential of both items of equipment to become more positive. Whereas when the apron was in contact with the table, the action of the ionizer initially promoted a strong negative surface potential $(>-500 \mathrm{~V})$, which then stabilized at approximately $-350 \mathrm{~V}$. However, after the ionizer was switched off, the apron rapidly lost this negative potential.

\section{Discussion and conclusion}

Numerous studies have implicated contamination of the clinical environment with outbreaks of Acinetobacter associated infection. For example, in a study conducted in an ICU, multiple-antibiotic-resistant Acinetobacter spp. isolates were recovered from bed surfaces, surfaces of equipment, floor mops (when dry) and curtains [18]. Pulsed field gel electrophoresis typing revealed the patients' isolates and those from the environment to be indistinguishable. Other studies have implicated the aerial dissemination of Acinetobacter spp. in the transmission of infection. Allen and Green [17] were the first to suggest airborne dissemination of Acinetobacter-carrying particles. Investigating an outbreak of multiply-antibiotic-resistant $A$. anitratus in an ICU, a medical ward and three neurosurgical wards, they cultured the outbreak strain from 16 of 82 settle plates. Das et al. [18] hypothesized that heavily contaminated bed curtains when moved would promote the airborne spread of Acinetobacter spp. Weernink et al. [19] investigated airborne dispersal of Acinetobacter spp. from patient's pillows. Using settle plates they found aerial dissemination from feather pillows, but not from synthetic pillows. Further evidence is provided by Houang et al. [21] who placed 70 settle plates in an ICU and 120 (in total) in four surgical wards. Remarkably, $96 \%$ of plates in the ICU and $89 \%$ in the surgical wards were culture-positive, demonstrating widespread airborne dispersal. Gerner-Smidt [22] recovered an outbreak of strain $A$. calcoaceticus subsp. anitratus from the air in an ICU using both settle plates and a slit sampler. Others have also shown Acinetobacter spp. to be readily culturable from hospital air [23,24].

In the clinical setting bacteria are readily liberated into the air through activities such as bed making and curtain shaking $[15,25]$. Furthermore, large numbers of bacteria (i.e. $>750$ bacteria per minute) may be aerially dissemi- 
Table 2: Mean air ion counts and air conditions recorded during the various experiments

\begin{tabular}{|c|c|c|c|c|}
\hline Experiment & $\begin{array}{l}\text { Negative ion count } \\
\text { (ions/cm3) }\end{array}$ & $\begin{array}{l}\text { Negative ion count } \\
\text { (ions/cm } 3 \text { ) }\end{array}$ & $\begin{array}{l}\text { Negative ion count } \\
\text { (ions/cm } 3 \text { ) }\end{array}$ & $\begin{array}{l}\text { Average air } \\
\text { condition }\end{array}$ \\
\hline & $\begin{array}{l}\text { Ionizer off } \\
(<600 \mathrm{~s})\end{array}$ & $\begin{array}{l}\text { lonizer on } \\
(600-2800 \mathrm{~s})\end{array}$ & $\begin{array}{l}\text { lonizer off } \\
(>2800 s)\end{array}$ & \\
\hline Ventilator tubing * & 770 & 28800 & 510 & $26.6^{\circ} \mathrm{C} \& 33.4 \% \mathrm{RH}$ \\
\hline Ventilator tubing $* *$ & 510 & 77200 & 480 & $25.1^{\circ} \mathrm{C} \& 40.2 \% \mathrm{RH}$ \\
\hline Mask* & 460 & 37100 & 300 & $22.3^{\circ} \mathrm{C} \& 41.6 \% \mathrm{RH}$ \\
\hline Mask ** & 1650 & 85600 & 430 & $23.3^{\circ} \mathrm{C} \& 40.2 \% \mathrm{RH}$ \\
\hline Nebulizer tubing * & 1230 & 84600 & 360 & $23.3^{\circ} \mathrm{C} \& 41.7 \% \mathrm{RH}$ \\
\hline Nebulizer tubing ** & 480 & 52200 & 340 & $23.5^{\circ} \mathrm{C} \& 41.3 \% \mathrm{RH}$ \\
\hline $\begin{array}{l}\text { Unometer }{ }^{\mathrm{TM}} \text { (measuring } \\
\text { chamber) * }^{*}\end{array}$ & 450 & 65500 & 240 & $23.9^{\circ} \mathrm{C} \& 39.8 \% \mathrm{RH}$ \\
\hline $\begin{array}{l}\text { Unometer }^{\mathrm{TM}} \text { (measuring } \\
\text { chamber) }\end{array}$ & 520 & 74300 & 240 & $24.4^{\circ} \mathrm{C} \& 38.4 \% \mathrm{RH}$ \\
\hline Unometer $^{T M}$ (tubing) * & 800 & 58600 & 360 & $23.7^{\circ} \mathrm{C} \& 42.8 \% \mathrm{RH}$ \\
\hline Unometer $^{\mathrm{TM}}$ (tubing) $* *$ & 390 & 56800 & 320 & $24.2^{\circ} \mathrm{C} \& 40.3 \% \mathrm{RH}$ \\
\hline Disposable apron * & 820 & 54300 & 670 & $24.3^{\circ} \mathrm{C} \& 37.8 \% \mathrm{RH}$ \\
\hline Disposable apron ** & 640 & 47800 & 420 & $24.3^{\circ} \mathrm{C} \& 37.3 \% \mathrm{RH}$ \\
\hline
\end{tabular}

nated from individuals undertaking activities within the clinical environment [26]. The charge carried by these airborne bacteria can be very high indeed, and is generally much greater than that carried by inert particles in the air $[27,28]$. This suggests that bacteria have inherently charged surfaces. Indeed, studies on waterborne bacteria indicate that they can carry thousands of elementary charge units [29]. If highly charged airborne bacteria pass through an electric field generated by a plastic object, then they are likely to move either towards, or away, from the surface depending on the polarity of the charges involved. Indeed, Allen et al. [20] in a study of plastic items of medical equipment, demonstrated that such equipment frequently becomes charged during routine activities (without the presence of ionizers) to such an extent that it attracts airborne bacteria.

Given that Acinetobacter-carrying particles are present in the air in many clinical settings, the electrostatic characteristics of the environment are likely to have a profound effect on their deposition. The data in figures 3,4 , $5,6,7$ and 8 suggest that negative air ionizers, if installed on a ward, are likely to significantly alter the surface potential of many items of plastic equipment, provided there is a sufficient ion generation rate within the ward space $[11,30]$. The results presented here indicate that the charge depends on the triboelectric properties of the material. However, it is probably that most non-conducting items of plastic equipment, such as ventilator and 


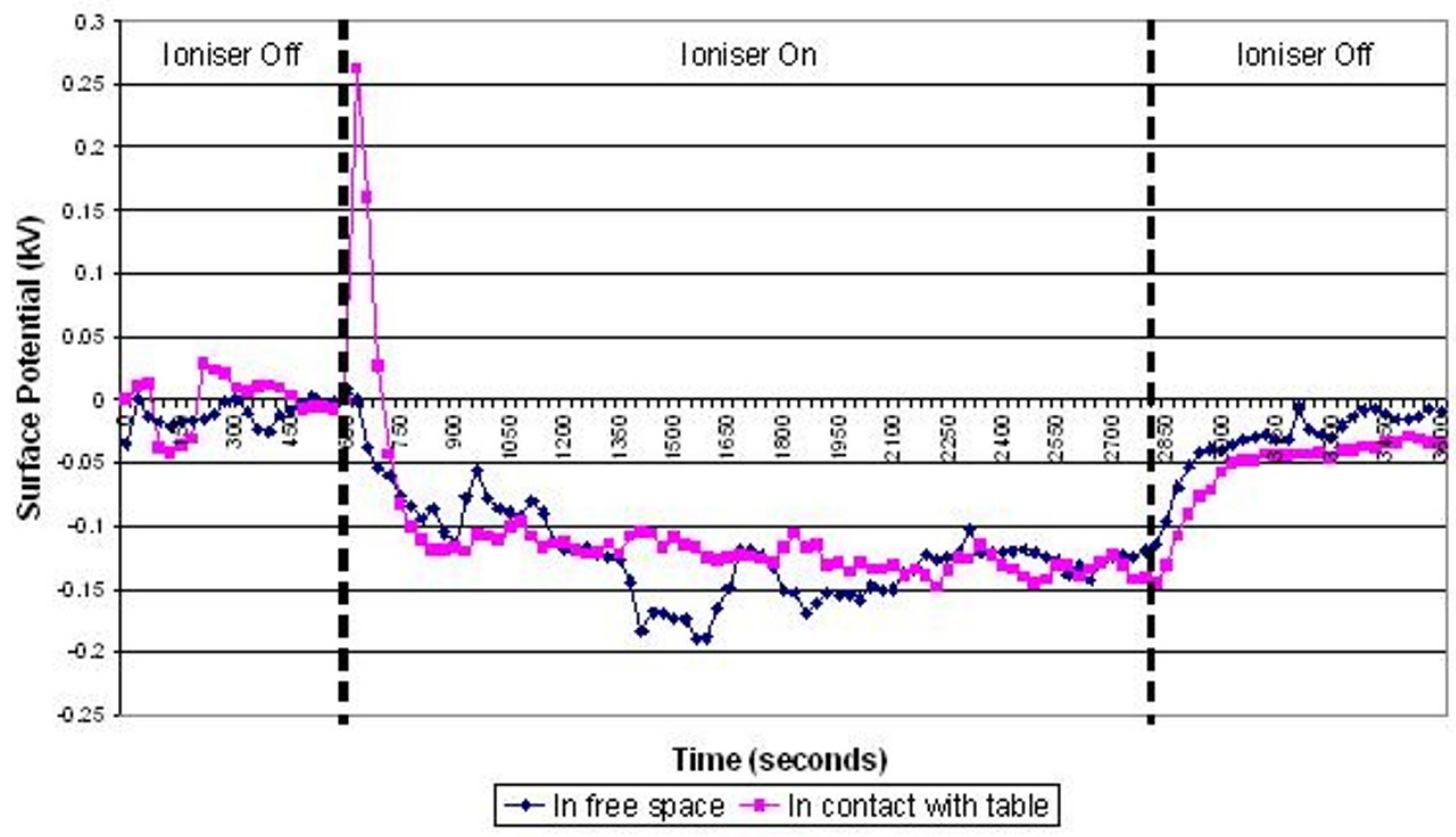

Figure 3 Change in surface potential over time for ventilator tubing in the presence of negative air ions

nebulizer tubes will take on a negative charge, while some other items may become positively charged. The particles in the air will also become predominantly negatively charged through a combination of field and diffusion charging [11], with the result that they will be repelled from negatively charged surfaces and attracted to positively charged or earthed materials.

From the results presented above it can be seen that in the presence of the ionizers most of the items of equipment developed a significant negative charge (i.e. in the region -100 to $-200 \mathrm{~V}$ ). For example, for the $25 \mathrm{~mm}$ diameter LDPE ventilator tube, which achieved an average potential of $-124 \mathrm{~V}$ and a capacitance of $14 \mathrm{pF}$ when in contact with the table, it can be calculated that the charge developed is $1.736 \times 10^{-9} \mathrm{C}$. Therefore, using equation 1 and the data presented in Table 1 , it can be calculated that an electric field of strength $42493 \mathrm{~V} / \mathrm{m}$ exists around the ventilator tube. If an airborne particle containing a unit charge (i.e. one additional electron) enters the electric field around the ventilator tube it will be repelled by a force of $6.81 \times 10^{-15} \mathrm{~N}$, which equates to a terminal velocity in the region 1.3 to $5.2 \mathrm{~mm} / \mathrm{s}$ for an $8 \mu \mathrm{m}$ particle, depending on its density. Given that when negative air ionizers are in operation, the vast majority of airborne particles will gain a negative charge, it is clear that an electrostatic repulsive force of this magnitude would ensure that many small to medium sized aerosol particles (1-8 $\mu \mathrm{m})$ will be deflected from the surface of the tube, with the result that surface contamination will be minimized. Given that in reality there will be other forces at play due to local air velocity, further studies coupling electrostatic effects with room airflows using simulation techniques are underway [11]. Initial results have shown that the extent to which repulsion or attraction occurs depends on particle size, ion generation rate and the magnitude of charge - thus supporting the findings presented here that suggest sufficient charge can be developed by an ionizer to change the deposition pattern on items of equipment with a relatively small surface area such as ventilator tubes. This may explain why the action of the negative air ionizers in Kerr et al's study [1] was associated with increased deposition of Acinetobacter-carrying particles on bed frames and VDU screens. If high charges are accumulated, then it is possible that even relatively substantial particles such as large skin squamae, that would otherwise settle out, could be repelled from sensitive surfaces.

Acinetobacter respiratory tract infections have been frequently associated with contamination of ventilators respiratory therapy equipment, including nebulizers. For example, Craven et al. [31] found that out of 19 nebulizers tested, $79 \%$ were contaminated predominantly with 


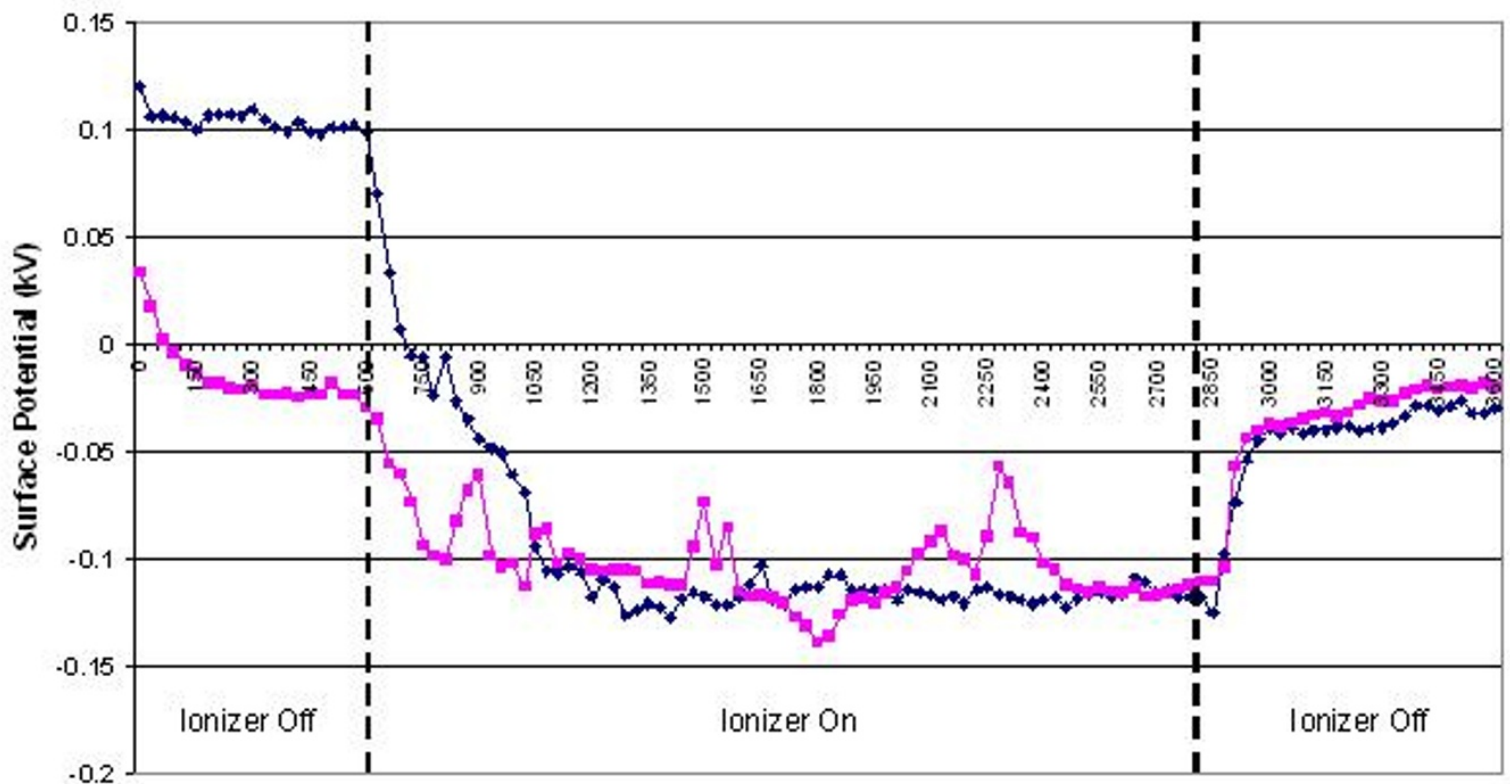

Time (seconds)

$\rightarrow-$ In free space - - In contact with table

Figure 4 Change in surface potential over time for the face mask in the presence of negative air ions.

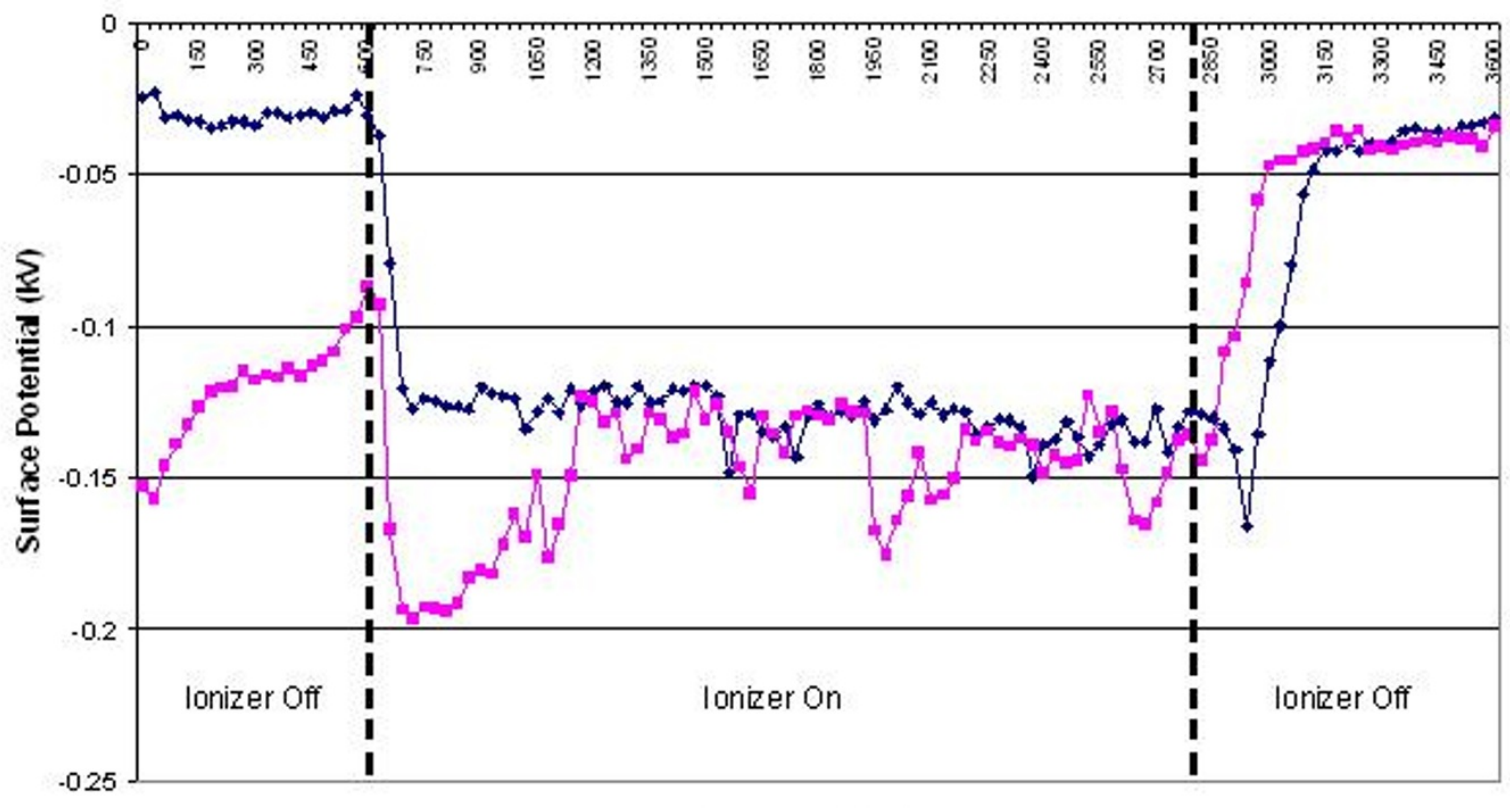

Time (seconds)

$\rightarrow-$ In free space - - Incontact with table

Figure 5 Change in surface potential over time for nebulizer tubing in the presence of negative air ions 


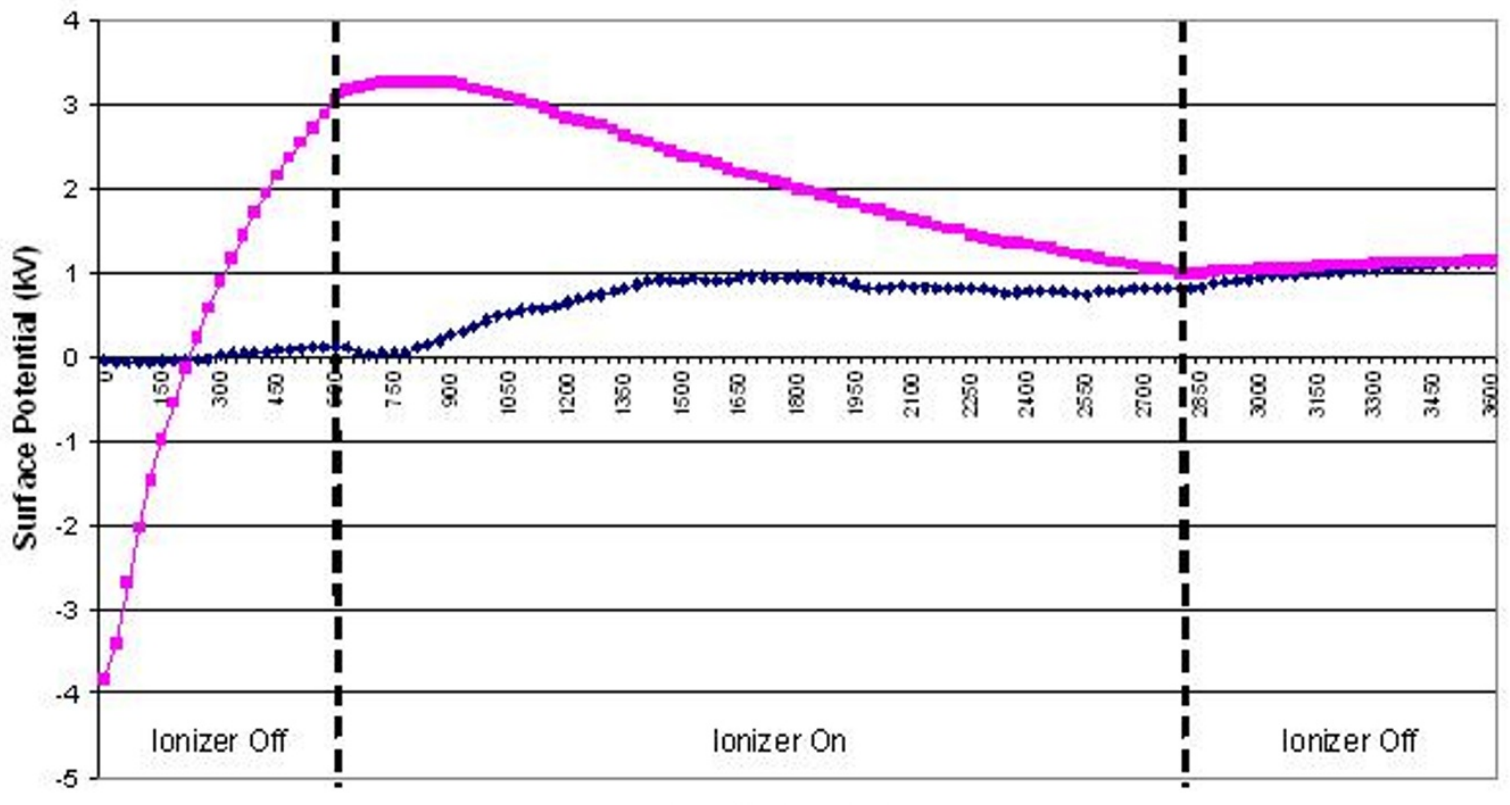

Time (seconds)

$\leftarrow$ In free space -- In contact with table

Figure 6 Change in surface potential over time for the Unometer ${ }^{\mathrm{TM}}$ measuring chamber in the presence of negative air ions

$71 \%$ of these generated bacterial aerosols with the resulting droplet nuclei of $<3 \mu \mathrm{m}$, capable of penetrating the distal airways of the lungs. It was found that the nebulizers had become contaminated by reflux from the patients mixing with condensate in the ventilator circuit. In another ventilator associated outbreak [32] contaminated ventilator tubing and humidifiers were identified as the source of infection. It was found that decontamination of the equipment was not occurring due to the action of a faulty washing machine. Replacing the reusable tubes with disposable tubing ended the outbreak. Dealler [33] reported an unusual outbreak of $A$. baumannii infection in an ICU involving the failure of the bacterial filter separating the patient from the ventilation tubing, with the result that outbreak strain was detected in the air near to the output ducts of the ventilation machines. Twenty-six of these filters were cultured and in 15 cases Acinetobacter had colonized the condensate on the patient side of the filter and could also be detected by swabbing on the equipment side, indicating failure of the filters. In addition, the outbreak strain was recovered from various parts of the ICU, including some locations untouched by the staff, suggesting that airborne dissemination of $A$. baumannii was taking place.

In our experiments the ventilator, nebuliser and urinary tubes (figures 3, 5 and 7) all exhibited similar behaviour when the ionizer was switched on. They all rapidly became negatively charged, which is not surprising given that these items of equipment are made from either polyethylene (PE) or polyvinylchloride (PVC), both of which are strongly negative in the triboelectric series [34,35] and therefore likely to gain electrons. The SealFlex ${ }^{\mathrm{TM}}$ mask (Figure 4) also behaved in a similar manner, suggesting that its triboelectric properties are similar to those of $\mathrm{PE}$ and PVC. Interestingly, all these items of equipment rapidly lost their negative charge once the ionizer was switched off. This phenomenon could have been due to bulk conduction, or alternatively charge loss may have occurred through the recombination of electrons with positive ions in the air [36]. The results in Figure 8 show that the polyethylene disposable apron, when in contact with the earthed table, performed in a similar manner to the ventilator, nebuliser and urinary tubes. However, when suspended in free space its behaviour was completely different, with its surface potential becoming more positive when the ionizer was in operation. The reasons for this are unclear.

From Figure 6 it can be seen that the data obtained for the Unometer ${ }^{\mathrm{TM}}$ measuring chamber were very different to those from the other items of equipment. This appears to be because this item was manufactured from styrene acrylonitrile (SAN), which is a much more 'positive' tri- 


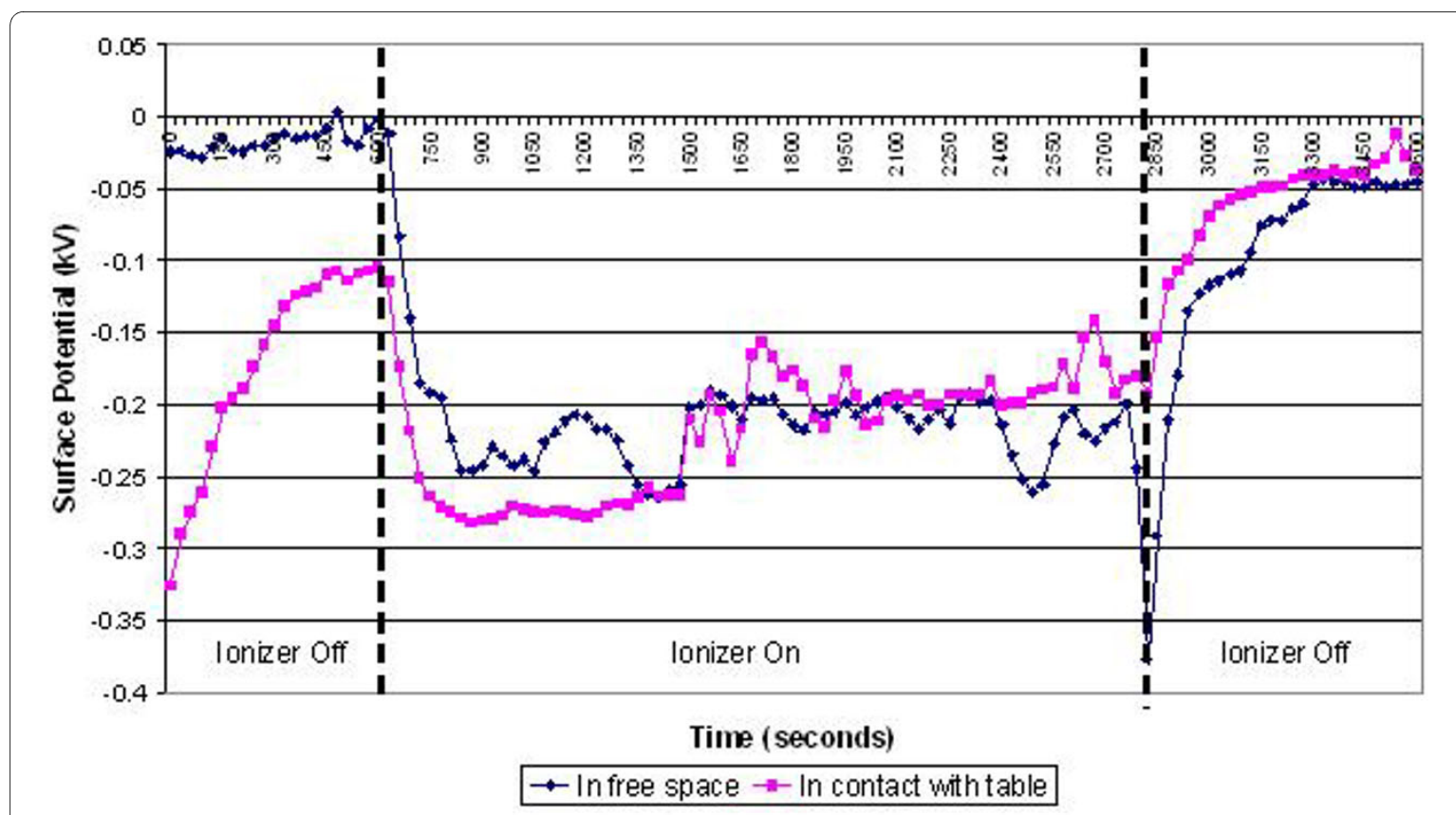

Figure 7 Change in surface potential over time for the Unometer ${ }^{\mathrm{Tm}}$ tubing in the presence of negative air ions.

boelectric material than either PE or PVC. Styrene acrylonitrile, like polystyrene (PS), is a polymer with a high electrical resistivity, which can hold either a positive or negative electrical charge for hours [37]. This probably explains why the Unometer ${ }^{\mathrm{Tn}}$ box retained a positive charge of approximately $100 \mathrm{~V}$ after the ionizer had been switched off.
Although the impact of corona discharges on polymers has been investigated by other researchers [36,38], to our best knowledge this is the first study of its kind to specifically examine the subject in a clinical context. As such, our results provide a plausible explanation for the observations of Kerr et al. [1] in their study of Acinetobacter infection/colonization on an ICU. Our findings suggest

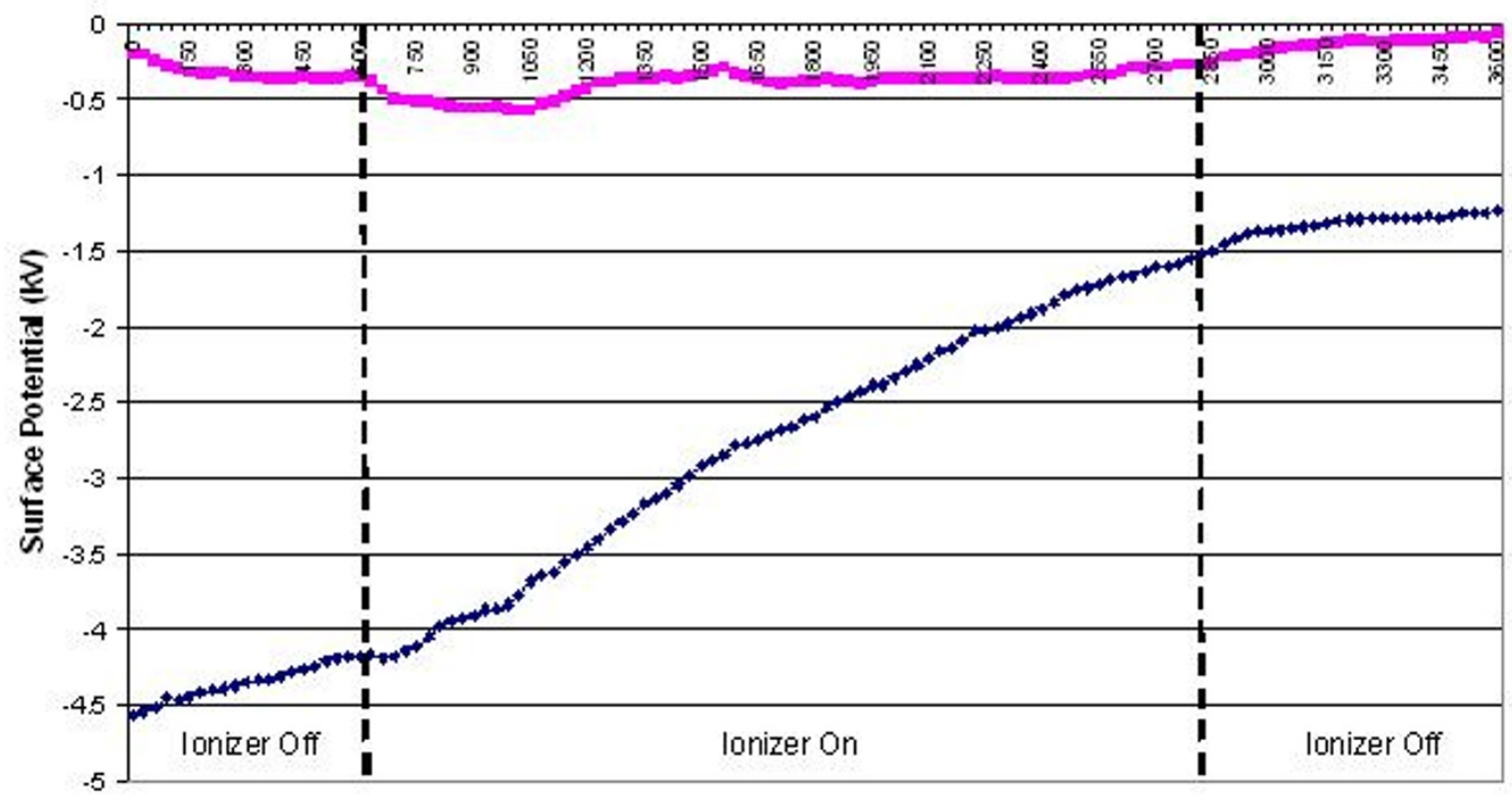

Time (seconds)

- In free space $-=-$ In contact with table 
that it is possible that the action of negative air ionizers in this setting changed the electrostatic characteristics of plastic items of equipment within the ICU environment, causing airborne particles to be strongly repelled from some surfaces or attracted to others. This is wholly consistent with the observations of Kerr et al., who found a marked increase in environmental isolates of Acinetobacter spp. to be associated with the operation of the ionizers. If this hypothesis is indeed the case, then it would suggest that observations of Kerr et al in their ICU-based study were related to the electric field created by the ionizers in the ICU and its subsequent effect on plastic devices rather than any direct antibacterial effect on Acinetobacter species.

\section{Competing interests}

The authors declare that they have no competing interests.

\section{Authors' contributions}

SJS, CBB, CJN and PAS designed the study. CFS and SJS undertook the experimental work. KGK advised on the clinical aspects of the study. CBB wrote the manuscript with major contributions from other authors. All authors have read and approved the final manuscript.

\section{Acknowledgements}

The authors would like to express their gratitude to the EPSRC for funding this study.

\section{Author Details}

'Bradford Infection Group, School of Engineering, Design and Technology, University of Bradford, Bradford, BD7 1DP, UK, 2Harrogate and District NHS Foundation Trust, Harrogate District Hospital, Lancaster Park Road, Harrogate, HG2 7SX, UK and 3Pathogen Control Engineering Institute, School of Civil Engineering, University of Leeds, Leeds, LS2 9JT, UK

Received: 24 June 2009 Accepted: 12 April 2010

Published: 12 April 2010

\section{References}

1. Kerr KG, Beggs CB, Dean SG, Thornton J, Donnelly JK, Todd NJ, Sleigh PA, Qureshi A, Taylor CC: Air ionisation and colonisation/infection with methicillin-resistant Staphylococcus aureus and Acinetobacter species in an intensive care unit. Intensive Care Med 2006, 32(2):315-317.

2. Noyce JO, Hughes JF: Bactericidal effects of negative and positive ions generated in nitrogen on Escherichia coli. J Electrostatics 2002, 54:179-187.

3. Digel I, Temiz Artmann A, Nishikawa K, Artmann GM: Cluster air-ion effects on bacteria and moulds. International Symposium on Cellular Engineering and Nanosensors (part of the 38th Annual Congress on Biomedical Engineering) 21 September 2004; Ilmenau, Germany 2004:1040-1041.

4. Shargawi JM, Theaker ED, Drucker DB, MacFarlane T, Duxbury AJ: Sensitivity of Candida albicans to negative air ion streams. J App/ Microbiol 1999, 87(6):889-897.

5. Kellogg EW, Yost MG, Barthakur N, Kreuger AP: Superoxide involvement in the bactericidal effects of negative air ions on Staphylococcus albus. Nature 1979, 281(5730):400-401.

6. Phillips G, Harris GJ, Jones MW: Effects of air ions on bacterial aerosols. Int J Biometeorolgy 1964, 8:27-37.

7. Furst R: Studies on ionization effects. In Annual Report Houston: Anderson Hospital, Houston University of Texas; 1955

8. Pratt R, Barnard RW: Some effects of ionized air on Penicillium notatum. J Am Pharm Assoc Sci 1960, 49:643-646.

9. Fletcher LA, Gaunt LF, Beggs CB, Shepherd SJ, Sleigh PA, Noakes CJ, Kerr KG: Bactericidal action of positive and negative ions in air. $B M C$ Microbiol 2007, 7:32
10. Noyce JO, Hughes JF: Bactericidal effects of negative and positive ions generated in nitrogen on starved Pseudomonas veronii. J Electrostatics 2003, 57:49-58.

11. Noakes C, Sleigh PA, Beggs CB: Modelling the air cleaning performance of negative air ionisers in ventilated rooms. Proceedings of the 10th international conference on air movement in rooms - Roomvent 2007: 13-15 June 2007: Helsinki 2007:1046-1056.

12. Lee $B U$, Yermakov M, Grinshpun SA: Removal of fine and ultrafine particles from indoor air environments by the unipolar ion emission. Atmospheric Environment 2004, 38:4815-4823.

13. Mayya YS, Sapra BK, Khan A, Sunny F: Aerosol removal by unipolar ionization in indoor environments. Journal of Aerosol Science 2004 35:923-941.

14. Grabarczyk Z: Effectiveness of indoor air cleaning with corona ionizers. Journal of Electrostatics 2001, 51-52:278-283.

15. Roberts K, Hathway A, Fletcher LA, Beggs CB, Elliott MW, Sleigh PA: Bioaerosol production on a respiratory ward. Indoor and Built Environment 2006, 15(1):35-40.

16. Beggs CB, Kerr KG, Noakes CJ, Hathway EA, Sleigh PA: The ventilation of multiple-bed hospital wards: review and analysis. Am J Infect Control 2008, 36(4):250-259

17. Allen $\mathrm{KD}$, Green $\mathrm{HT}$ : Hospital outbreak of multi-resistant Acinetobacter anitratus: an airborne mode of spread? J Hosp Infect 1987, 9(2):1 10-119.

18. Das I, Lambert P, Hill D, Noy M, Bion J, Elliott T: Carbapenem-resistant Acinetobacter and role of curtains in an outbreak in intensive care units. J Hosp Infect 2002, 50(2):110-114.

19. Weernink A, Severin WP, Tjernberg I, Dijkshoorn L: Pillows, an unexpected source of Acinetobacter. J Hosp Infect 1995, 29(3):189-199.

20. Allen JE, Close JJ, Henshaw DL: Static electric fields as a mediator of hospital infection. Indoor and Built Environment 2006, 15(1):49-52.

21. Houang ET, Chu YW, Leung CM, Chu KY, Berlau J, Ng KC, Cheng AF: Epidemiology and infection control implications of Acinetobacter spp. in Hong Kong. J Clin Microbiol 2001, 39(1):228-234.

22. Gerner-Smidt P: Endemic occurrence of Acinetobacter calcoaceticus biovar anitratus in an intensive care unit. J Hosp Infect 1987, 10(3):265-272.

23. Thornton T, Fletcher LA, Beggs CB, Elliott MW, Kerr KG: Airborne microflora in a respiratory ward. ASHRAE IAQ Conference: 15 - 17th March 2004; Tampa, Florida: ASHRAE 2004

24. Obbard JP, Fang LS: Airborne concentrations of bacteria in a hospital environment in Singapore. Water, Air, and Soil Pollution 2003 144:333-341.

25. Ayliffe GAJ, Babb JR, Taylor LJ: Hospital-acquired infection - principles and prevention. London, Butterworth-Heinemann; 1999.

26. May KR, Pomeroy NP: Bacterial dispersion from the body surface. In Airborne transmission and airborne infection Edited by: Hers JF, Winkler KC. Utrecht: Oosthoek Publishing Company; 1973.

27. Willeke K, Mainelis G, Grinshpun SA, Reponen T, Baron P: Measurement of electrical charges on airborne microorganisms. Journal of Aerosol Science 2000, 31(Suppl 1):S957-S958.

28. Mainelis G, Willeke K, Baron P, Reonen T, Grinshpun SA, Gorny RL, Trakumas S: Electric charges on airborne microorganisms. Journal of Aerosol Science 2001, 32:1087-1110.

29. Sherbet GV, Lakshmi MS: Characterisation of Escherichia coli cell surface by isoelectric equilibrium analysis. Biochim Biophys Acta 1973, 298(1):50-58.

30. Fletcher $L A$, Noakes $C J$, Sleigh PA, Beggs $C B$, Shepherd SJ: Air ion behavior in ventilated rooms. Indoor and Built Environment 2008, 17:173-182.

31. Craven DE, Lichtenberg DA, Goularte TA, Make BJ, McCabe WR: Contaminated medication nebulizers in mechanical ventilator circuits. Source of bacterial aerosols. Am J Med 1984, 77(5):834-838.

32. Cefai C, Richards J, Gould FK, McPeake P: An outbreak of Acinetobacter respiratory tract infection resulting from incomplete disinfection of ventilatory equipment. J Hosp Infect 1990, 15(2):177-182.

33. Dealler S: Nosocomial outbreak of multi-resistant Acinetobacter sp. on an intensive care unit: possible association with ventilation equipment. J Hosp Infect 1998, 38(2):147-148.

34. Davies DK: Charge generation on dielectric surfaces. J Phys D: Appl Phys 1969, 2:1533-1537.

35. Diaz AF, Felix-Navarro RM: A semi-quantitative tribo-electric series for polymeric materials: the influence of chemical structure and properties. Journal of Electrostatics 2004, 62(4):277-290. 
36. Xu Z, Zhang L, Chen G: 2007 International Conference on Solid Dielectrics. July 8-13 2007; Winchester, UK 2007.

37. Tsai P, Schreuder-Gibson HL: Fiber charging effects on target coverage in electrospinning. INTC2003, International Nonwovens Technical

Conference: 15-18 September 2003; Baltimore, USA 2003:403-413.

38. Chubb JN: Corona charging of practical materials for charge decay measurements. Journal of Electrostatics 1996, 37(1):53-65.

Pre-publication history

The pre-publication history for this paper can be accessed here: http://www.biomedcentral.com/1471-2334/10/92/prepub

doi: 10.1186/1471-2334-10-92

Cite this article as: Shepherd et al., Effect of negative air ions on the potential for bacterial contamination of plastic medical equipment BMC Infectious Diseases 2010, 10:92

Submit your next manuscript to BioMed Central and take full advantage of:

- Convenient online submission

- Thorough peer review

- No space constraints or color figure charges

- Immediate publication on acceptance

- Inclusion in PubMed, CAS, Scopus and Google Scholar

- Research which is freely available for redistribution

Submit your manuscript at www.biomedcentral.com/submit
C Biomed Central 